\title{
PENGARUH RASIO-RASIO KEUANGAN TERHADAP HARGA SAHAM SEKTOR AGRIKULTUR DI BURSA EFEK INDONESIA PERIODE 2014-2018
}

\author{
Lingga Sundagumilar Abqari \\ Universitas Negeri Surabaya \\ linggaabqari16080574148@mhs.unesa.ac.id \\ Ulil Hartono \\ Universitas Negeri Surabaya \\ ulilhartono@unesa.ac.id
}

\begin{abstract}
The objectives to be achieved by this research are knowing the effect of the ratio of return on equity, earnings per share, price earning ratio, and the debt to equity ratio to stock prices in the agricultural sector on the Indonesia Stock Exchange in the 2014-2018 period. This study has a population that is used namely agricultural sector companies recorded on the Stock Exchange in the 2014-2018 period upwards of 17 companies. Multiple linear regression analysis methods were utilized in this study. Based on conclusions, there is a negative effect of the ratio of return on equity $(X 1)$ to stock prices $(Y)$ in the first hypothesis test. For the subsequent hypothesis testing the conclusions indicate that the earnings per share ratio (X2) has a positive effect on stock prices $(Y)$. This study also found that the price earning ratio (X3) harmed stock prices $(Y)$ in the third hypothesis test. While the fourth hypothesis test shows that the debt to equity ratio (X4) does not affect stock prices $(Y)$. This happens because of the movement of each variable on stock prices.
\end{abstract}

Keywords: DER (Debt to Equity Ratio); EPS (Earning Per Share); PER (Price Earning Ratio); ROE (Return on Equity); stock price.

\section{PENDAHULUAN}

Menurut (Tandelilin, 2010), tempat untuk pihak dengan dana berlebih dan pihak yang butuh dana akan saling bertemu untuk menyelenggarakan investasi dengan cara bertransaksi surat berharga disebut pasar modal. Selain itu, pasar modal didefiniskan selaku pasar tempat jual beli sekuritas yang biasanya mempunyai periode waktu di atas satu tahun, contohnya obligasi dan saham. Sedangkan bursa efek ialah tempat dimana transaksi sekuritas itu berlangsung. Negara Indonesia mempunyai bursa efek sendiri yang dinamai Bursa Efek Indonesia (BEI). Perusahaan-perusahaan yang telah mendaftarkan dirinya ke Bursa Efek Indonesia atau go public menerbitkan surat berharga atau efek berupa saham yang tersedia untuk para investor. Pertimbangan diperlukan oleh seorang investor untuk bertransaksi saham di bursa efek.

Menurut Zuliarni (2012), harga saham adalah satu dari sekian banyak indikator yang dapat membuktikan bahwa suatu perusahaan mampu melakukan pengelolaan yang baik. Jika perusahaan tersebut sering mengalami kenaikan harga saham, maka perusahaan itu akan dinilai sebagai perusahaan yang berhasil dalam mengelola usaha oleh calon investor atau investor. Kepercayaan calon investor atau investor itu sangat bermanfaat bagi emiten, sebab keinginan untuk berinvestasi pada emiten tersebut akan menguat dengan semakin banyaknya orang yang percaya padanya. Kepercayaan calon investor atau investor kepada emiten akan semakin tinggi dan nilai emiten akan naik jika permintaan saham dari suatu emiten semakin banyak. Sebaliknya, nilai emiten di mata calon investor atau investor akan mengalami penurunan dengan penurunan harga saham terus-menerus. Dikutip dari (BI, 2016), harga komoditas global terus mengalami koreksi pada tahun 2015. Pada tahun 2015 pertumbuhan tahunan Indeks Harga Komoditas Ekspor Indonesia (IHKEI) terkontraksi 15\%. Pada tahun 2015 pertumbuhan IHKEI menjadi semakin negatif jika dibandingkan dengan pada tahun 2014 yang mengalami kontraksi sebesar 4,2\%. Pelemahan yang dialami ekonomi global terutama lambatnya ekonomi Tiongkok sebagai negara konsumen utama dari produk ekspor Indonesia, menyebabkan Kontraksi IHKEI semakin dalam. Kuatnya korelasi antara pertumbuhan ekonomi Tiongkok dan indeks 
harga komoditas dunia non-fuel sebesar 0,7 mencerminkan hubungan yang erat antara perekonomian Tiongkok dan harga komoditas.

Perusahaan agrikultur adalah perusahaan yang memproduksi panganan, serat, makanan dan hasil-hasil lainnya pada sektor pertanian yang dibutuhkan oleh manusia. Termasuk juga tanaman-tanaman tertentu dan juga pertambahan hewan-hewan lokal. Terdapat lima sub sektor dalam sektor agrikultur yakni tanaman pangan, perkebunan, peternakan, perikanan, dan kehutanan. Selama ini harga saham perusahaan sektor agrikultur sangat bergantung pada harga minyak kelapa sawit/crude palm oil (Artha et al., 2014). Dikutip dari (Okefinance, 2016) penurunan harga komoditas ekspor Indonesia tahun 2015 bersumber pada turunnya harga batubara, minyak kelapa sawit, dan karet. Oversupply minyak kelapa sawit di Malaysia menyebabkan harga minyak kelapa sawit mengalami penurunan sebesar 8,2\%. Selain itu, harga kacang kedelai dan minyak dunia yang rendah sebagai barang substitusi juga menyebabkan penurunan harga minyak kelapa sawit. Harga minyak kelapa sawit sangat memengaruhi harga saham perusahaan-perusahaan di sektor agrikultur hingga akhirnya membuat indeks harga saham sektor agrikultur melemah jauh dari Rp2.245,84 pada tahun 2015 menjadi Rp1.741,93 per lembar saham. Sebagai gambaran, berikut menunjukkan data sejumlah harga saham sektoral di Bursa Efek Indonesia pada periode 2014-2018:

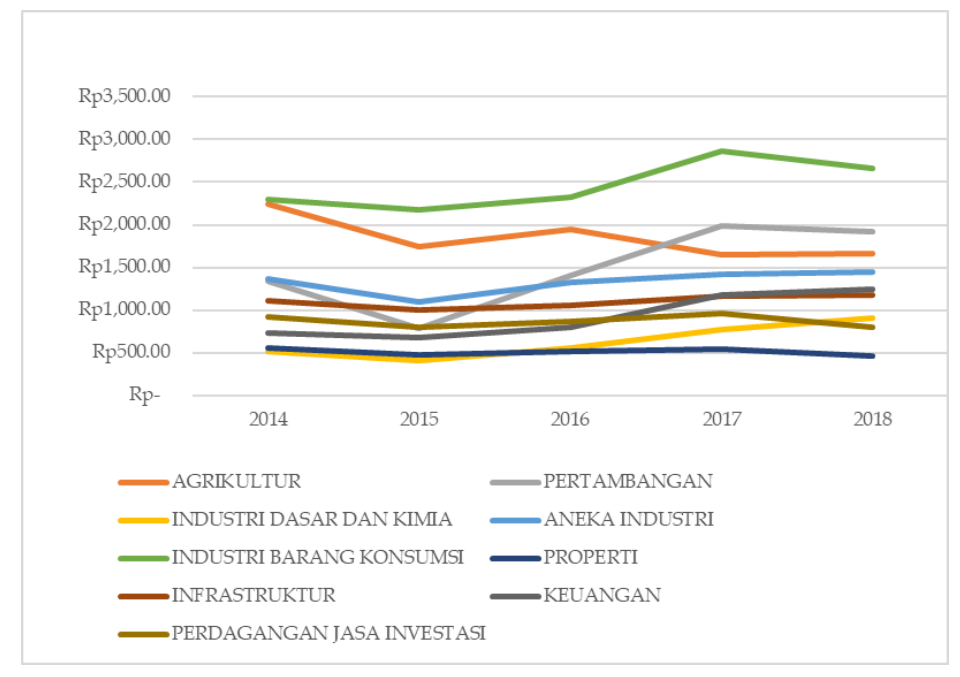

Sumber: Investing.com (2020), diolah penulis

\section{Gambar 1. Grafik Data Harga Saham Sektoral BEI 2014-2018}

Gambar 1 menunjukkan grafik data harga saham sektoral di Bursa Efek Indonesia periode 2014-2018. Harga saham yang fluktuatif dan tidak menentu acap kali membuat investor atau calon investor bingung memilih saham yang terbaik bagi mereka. Terlihat sektor agrikultur adalah sektor yang harga sahamnya sangat menurun dibanding delapan sektor yang lain. Dari harga saham senilai Rp2245.84 pada tahun 2014 menurun cukup curam menuju Rp1661.96 di tahun 2018. Sedangkan peningkatan yang signifikan terjadi pada sektor pertambangan yang menanjak dari tahun 2015 hingga kemudian mengalami stagnansi pada tahun 2017 (Investing.com, 2020).

Analisis secara mendalam diperlukan untuk meminimalkan risiko yang terjadi. Oleh karena itu, diperlukan analisis secara fundamental maupun teknikal. Analisis yang melihat data-data pasar saham pada masa lampau selaku dasar analisis disebut analisis teknikal. Analisis ini dapat meramal naik turunnya harga masa depan dengan memakai grafik. Sementara itu, analisis fundamental yaitu analisis yang meramal harga saham di hari esok menggunakan metode melihat nilai-nilai faktor fundamental yang berpengaruh dan menyambungkan tiap variabel yang tersedia (Kodrat \& Indonanjaya, 2010). Dalam penelitian ini, akan menitikberatkan pada analisis fundamental menggunakan ROE, EPS, PER, dan DER. 
Menurut Kasmir (2012:204), ROE atau hasil pengembalian ekuitas adalah rasio yang berguna menilai laba bersih sesudah pajak dibandingkan menggunakan modal sendiri. Jika nilai ROE tinggi, maka perusahaan akan baik karena semakin tinggi ROE diartikan efiensisi perusahaan yang tinggi. Dalam penelitian Hidayat \& Topowijono (2018) dinyatakan bahwa ROE memberi pengaruh yang negatif pada pergerkan harga saham. Akan tetapi, Arifin \& Agustami (2016) menyatakan bahwa ROE berpengaruh signifikan positif terhadap harga saham. Hasil penelitian ini sesuai dengan hasil penelitian Ananda (2013). Begitu pula dengan penelitian Kamar (2017) yang menyatakan bahwa ROE memiliki pengaruh signifikan positif terhadap harga saham perusahaan semen yang terdaftar di Bursa Efek Indonesia dari tahun 2011 sampai tahun 2015. Namun hasil berbeda didapatkan oleh hasil penelitian Utomo \& Hartono (2014) yang menyatakan bahwa ROE tidak berpengaruh terhadap harga saham. Begitupun dengan Sari, et. al (2013) di mana dalam penelitiannya ROE tidak berpengaruh secara signifikan terhadap perubahan harga saham.

Menurut Tandelilin (2010), rasio yang menilai seberapa banyak laba yang diterima dari tiap-tiap lembar saham yang telah beredar disebut EPS. Emiten dianggap memiliki kinerja yang baik jika nilai EPS tinggi. Beberapa penelitian terdahulu, EPS dapat memberikan pengaruh positif yang signifikan pada saham seperti penelitian Hanum (2011). EPS kerap dipakai oleh para investor sebab para investor merasa informasi dari EPS suatu perusahaan dapat memberi seberapa besar laba bersih perusahaan yang yang dapat dibagikan, dengan kata lain mencerminkan prospek earning perusahaan di masa mendatang, maka dari itu EPS sering dijadikan acuan dalam pengambilan keputusan investasi saham. Hasil penelitian berbeda ditunjukkan oleh penelitian yang dilakukan oleh Utomo \& Hartono (2014) yang menyatakan bahwa EPS tidak bepengaruh terhadap harga saham. Hal ini disebabkan karena sebagian besar perusahaan sektor pertambangan selama periode penelitian mengalami penurunan laba bersih sehingga kemampuan perusahaan dalam memperoleh laba yang tersedia untuk setiap pemegang saham relatif rendah. Penelitian Ramfineli \& Ibrahim (2016) mendukung hasil penelitian tersebut.

Berdasarkan Hanafi \& Halim (2009), rasio yang membandingkan nilai harga saham di pasar dengan keutungan yang didapatkan dari tiap-tiap lembar saham terjual disebut PER. PER menunjukkan besaran uang yang wajib diserahkan investor guna mendapatkan laba perusahaan. Zuliarni (2012) dalam penelitiannya menyatakan bahwa PER berpengaruh signifikan positif terhadap harga saham perusahaan mining and mining service. Hasil penelitian ini didukung oleh penelitian Mehrani \& Syafitri (2013) yang dalam penelitian ini ditunjukkan bahwa variabel PER dapat digunakan untuk memprediksi kemampuan perusahaan dalam menghasilkan laba di masa yang akan datang. Dalam penelitian Hidayat \& Topowijono (2018), PER memberi dampak yang cenderung negatif dalam pergerakan harga saham. Pengaruh negatif yang ditemukan pada penelitian ini didasarkan oleh beberapa perusahaan mempunyai angka PER negatif yang cukup besar.

DER ialah rasio keuangan yang memperkirakan kecakapan perusahaan untuk melunasi tunggakan menggunakan modal yang mereka miliki (Husnan \& Pudjiastuti, 2006:70). Artinya kian besar DER yang dimiliki emiten, kian besar pula kemampuan perusahaan untuk melunasi utang-utang perusahaan termasuk utang jangka pendek dan panjang menggunakan modal mereka sendiri. Munira et. al (2018) menyatakan bahwa DER memiliki pengaruh signifikan positif terhhadap harga saham. Analisis pengaruh kinerja keuangan yang diwakili dengan DER terhadap harga saham pada perusahaan sub sektor pulp \& paper yang tercatat di BEI selama tahun 2012-2016 yaitu bahwa secara parsial variabel DER berpengaruh signifikan terhadap harga saham. Akan tetapi hasil berbeda dinyatakan pada penelitian Daniel (2015) yaitu DER tidak memberi pengaruh yang besar terhadap harga saham, sebab DER sama dengan proporsi antara total utang dan total modal. Maka dengan mengambil kebijakan yang membesarkan utang, berarti manajemen sama saja dengan meningkatkan tingkat risiko likuiditas.

Penelitian bertujuan menganalisis pengaruh rasio-rasio keuangan seperti ROE, EPS, PER, dan DER terhadap harga saham sektor agrikultur yang terdaftar di Bursa Efek Indonesia pada periode 2014- 2018. 


\section{KAJIAN PUSTAKA DAN PENGEMBANGAN HIPOTESIS}

\section{Signaling theory}

Menjelaskan bagaimana suatu perusahaan membagi sinyal yang berisi infomasi kepada para investor. Petunjuk sinyal akan berisi tentang informasi semua tindakan yang telah dilakukan pihak manajemen dalam mewujudkan keinginan pihak yang bersangkuatan seperti pemilik perusahaan dan investor. Sinyal positif bisa berbentuk informasi atau promosi lain yang berisi bahwa perusahaan tersebut akan mempunyai masa depan yang unggul dibandingi perusahaan lain (Saleh, 2012). Mengacu pada Setyawan (2012), perusahaan akan memberi sinyal-sinyal kepada investor untuk pengambilan keputusan secara jelas. Sinyal itu biasanya ada dua macam yaitu berupa bad news ataupun good news. Sinyal good news bisa berbentuk laporan kinerja perusahaan yang tumbuh tiap tahun, sedangkan sinyal bad news berbentuk laporan kinerja perushaan yang mengalami penurunan. Semua informasi yang dibagikan menjadikan bahan perhatian para investor dalam pengambilan keputusan. Tindakan jual beli saham dipertimabangkan pemilik saham berdasarkan sinyal yang ada. Sinyal yang positif untuk para pemegang saham didapatkan dari harga saham yang terus naik, yang diakibatkan oleh kondisi keuangan perusahaan yang baik. Salah satu contoh perusahaan mampu memberi sinyal positif kepada pihak luar ialah dengan membayarkan dividen tunai dalam jumlah yang relatif besar. Pada penelitian ini, Signaling theory digunakan untuk menjelaskan bagaimana ROE, EPS, PER berpengaruh kepada harga saham.

\section{Trade Off Theory}

Mengacu pada Pertiwi (2016), teori trade off mempunyai dugaan jika perusahaan mencanangkan suatu target dari utang (debt ratio) untuk meningkatkan nilai pasar. Target utang ini dinamakan trade off dari bankruptcy dan tax benefit. Teori ini akan menerangkan ketika perusahaan mencanangkan target dari utang, maka perusahaan bisa meraihkan laba lebih dari pajak (tax benefit) yang diterima. Laba tambahan yang diraih perusahaan bisa disebabkan karena pajak yang dibayarkan perusahaan lebih kecil dibandingkan saat membayar bunga dai utang. Sebaliknya, jika perusahaan menambahkan tingkat utangnya, maka bankruptcy cost akan dialami. Pada teori ini dijelaskan bahwa dengan bertambahnya nilai utang, harga saham juga ikut meningkat. Namun hal ini mampu terjadi penurunan kembali jika tingkat utang berada pada titik optimal. Perusahaan yang memanfaatkan utang melebihi batas titik optimal akan berujung pada bankruptcy cost sebab tidak lagi mampu untuk melunasi utang dan juga bunga yang didapatkan dari utang tersebut. Maka teori ini mempu memprediksi ditemui hubungan positif antara saham dengan struktur modal. Keuntungan yang didapatkan dari pengurangan kewajiban pajak perusahaan akan menyebabkan kenaikan pada nilai arus kas sesudah pajak. Ini akan berdampak besar dibanding biaya tekanan finansial dan biaya keagenan. Pada penelitian ini, trade off theory digunakan untuk menjelaskan bagaimana DER berpengaruh kepada harga saham.

\section{Harga Saham}

Sartono (2008:70) mengemukakan bahwa proses permintaan dan penawaran yang terjadi akan membentuk harga saham pada pasar modal. Ketika jumlah permintaan banyak akan menyebabkan kenaikan harga saham. Sedangkan jika terjadi penawaran yang lebih banyak maka menyebabkan turunnya harga saham. Jogiyanti (2008:167), menjelaskan bahwasanya nilai harga saham yang terbentuk di bursa pasar modal sungguh bergantung akan permintaan serta penawaran yang berlangsung saat itu. Brigham \& Houston (2010:7) menyatakan kekayaan yang dimiliki pemegang saham dapat digambarkan oleh harga saham itu sendiri. Kekayaan pemegang saham yang optimal menjadi diinterpretasikan sebagai nilai harga saham yang maksimal. Harga saham yeng terbentuk diwaktu tertentu ditentukan dari arus yang akan didapatkan pada masa depan oleh investor ketika melakukan penawaran saham. Menurut penjelasan oleh para ahli yang telah disebutkan maka didapati bahwasanya harga saham ialah harga yang terwujud karena permintaan dan penawaran yang terjadi di pasar saham serta umumnya adalah harga penutupan.

\section{Return On Equity}

ROE bisa dijelaskan sebagai representasi kapabilitas perusahaan guna meraup laba sesudah pajak dengan cara memanfaatkan modal yang dipunyai oleh perusahaan (Sudana, 2009:26). Utomo \& Hartono (2014) menerangkan, ROE adalah faktor mikro (internal perusahaan) yang dipatok para 
investor di pasar modal sebagai salah satu bahan pertimbangan untuk menentukan keputusan investasinya. Teori yang dapat dipakai guna mengamati hubungan ROE terhadap harga saham ialah signaling theory. Teori ini menjelaskan bahwasanya laporan keuangan yang mencantumkan ROE ditetapkan investor sebagai sumber informasi untuk menimbang suatu saham di suatu perusahaan. Semakin tinggi tingkat profitabilitas atau keuntungan sebuah perusahaan, maka akan menyampaikan sinyal positif terhadap investor untuk memengaruhi keputusan investor menanamkan modalnya dalam bentuk saham. Rumus untuk menghitungnya dapat ditinjau pada rumus (1).

ROE $=\frac{\text { Laba Bersih Setelah Pajak }}{\text { Total Ekuitas }}$

\section{Earning Per Share}

EPS ialah keuntungan bersih yang tersedia guna dialokasikan untuk jajaran pemilik saham dibagi dengan jumlah lembar saham perusahaan (Tandelilin, 2010:373). Jiwandono (2014) menjelaskan bahwasanya investor akan memerhatikan berbagai aspek dalam berinvestasi di bursa efek, satu diantaranya yaitu penghasilan per lembar saham atau disebut EPS. EPS ialah penanda yang bisa menggambarkan kinerja suatu perusahaan, jikalau nilai EPS kian tinggi, maka bisa diinterpretasikan bahwasanya kian tinggi pula jumlah laba yang disiapkan perusahaan untuk jajaran pemilik saham perusahaan tersebut dan EPS juga krusial dalam analisis fundamental. Utomo \& Hartono (2014) menerangkan jika signaling theory dapat dipakai guna memahami hubungan EPS terhadap perubahan harga saham dikarenakan EPS yang tercantum dalam laporan keuangan perusahaan itu bisa menyampaikan informasi kepada investor guna membaca prospek earning perusahaan itu di masa depan. Jikalau nilai EPS yang terkandung dalam laporan keuangan perusahaan itu tinggi maka akan menyampaikan berita baik atau sinyal yang positif bagi investor. Berikut ialah rumus (2) yang dipakai untuk mengetahui nilai EPS.

EPS $=\frac{\text { Laba Bersih }}{\text { Jumlah Saham Beredar }}$

\section{Price Earning Ratio}

Menurut Hanafi \& Halim (2009:85), Rasio yang membandingkan harga saham dengan pendapatan harga saham dengan penpapatan tiap lembar saham disebut PER. Selain itu, bisa dijaikan sebagai penanda perkembangan ataupun pertumbuhan perusahaan di masa depan (prospects of the firm). (Inndiarti, 2016) menjelaskan bahwasanya kian besar nilai PER sebuah perusahaan, maka akan kian mahal harga sahamnya, serta juga semakin bagus nilai perusahaan tersebut. Perusahaan yang mempunyai perkembangan tinggi memiliki PER yang tinggi memberikan informasi bahwa pasar mengidamkan laba yang terus tumbuh di masa depan. Apabila PER rendah maka laba perusahaan cenderung tumbuh sedikt sehingga berpengaruh dalam penentuan harga saham sehingga menjadikan nilai perusahaan menurun. PER bisa dirumuskan melalui rumus (3) sebagai berikut.

PER $=\frac{\text { Harga Per Lembar Saham }}{\text { Earning Per Share }}$.

\section{Debt to Equity Ratio}

Seperti yang dipaparkan (Kasmir, 2015:157), rasio yang menunjukan proporsi seberapa banyak nilai utang dengan ekuitas suatu perusahaan disebut DER. Rasio diperoleh dari membandingakan semua utang yang ada dengan semua ekuitas hingga menghasilkan suatu nilai. Rasio ini berfungsi sebagai cara menaksir jumlah uang yang dipinjam dengan jumlah pemilik perusahaan. Rumus untuk mendapatkan nilai DER ialah seperti yang tercantum pada rumus (4) berikut.

DER $=\frac{\text { Total Hutang }}{\text { Ekuitas }}$.

\section{Hubungan antar Variabel}

ROE sebagaimana dikemukakan oleh Maskun (2012) adalah ukuran kinerja perusahaan dilihat dari segi profitabilitasnya. Profitabilitas merupakan kecakapan perusahaan guna meraup laba. Laba yang laik 
dibagikan untuk pemilik saham yaitu laba sesudah bunga dan pajak. Kecakapan meraup laba bersih sesudah pajak akan modal yang dipunyai perusahaan melukiskan performa yang kian cemerlang. Jika ROE kian tinggi maka kian tinggi pula tingkat pengembalian yang didambakan.

H1: ROE berpengaruh terhadap harga saham pada perusahaan sektor agrikultur di Bursa Efek Indonesia periode 2014-2018.

Tandelilin (2010) menjelaskan bahwa EPS yaitu rasio yang dapat memberikan informasi kuantitas keuntungan yang akan diraup tiap investor per lembar saham yang dimilikinya. Laporan keuangan perusahaan digunakan sebagai sumber informasi dalam mengeolah nilai EPS. Nilai EPS yang tinggi, sehingga laba perusahaan turut tinggi pula. Sehingga, jika perusahaan punya nilai EPS tinggi maka dapat menarik minat investor karena dividen yang akan diberikan besar pula sesuai laba yang diraup perusahaan. Oleh karena itu, harga saham mengalami kenaikan.

H2: EPS berpengaruh terhadap harga saham pada perusahaan sektor agrikultur di Bursa Efek Indonesia periode 2014-2018.

Sebagaimana yang dikemukakan Zuliarni (2012), Rasio yang manfaatkan sebagai alat penaksir kapabilitas perusahaan guna meraup laba disebut PER. Nilai PER yang tinggi dapat menarik minat investor yang tingga pula untuk menyelenggarakan investasi di perusahaan itu. Sehingga, mengakibatkan harga saham naik dan laba per lembar naik juga

H3: PER berpengaruh terhadap harga saham pada perusahaan sektor agrikultur di Bursa Efek Indonesia periode 2014-2018.

Menurut Sewi \& Suayana (2013), investor tidak mengarah pada keutungan laba perusahaan saja, tetapi juga akan memerhatikan kemungkinan risiko yang akan terjadi pada perusahaan itu. Tingkat risiko perushaan dicerminkan oleh nilai rasio DER yang memperlihatkan jumlah modal yang disediakan dalam hal untuk memenuhi kewajibannya. Semua investor tentu akan menghindari invesasi ke perusahaan yang mempunyai nilai DER tinggi karena angka yang besar menunjukkan risiko yang besar juga. Ini sangat memengaruhi keputusan investor yang membuat harga saham dapat mengalami penurunan.

H4: DER berpengaruh terhadap harga saham pada perusahaan sektor agrikultur di Bursa Efek Indonesia periode 2014-2018.

\section{METODE PENELITIAN}

Pendekatan kuantitatif yang berjenis kausal atau sebab-akibat digunakan dalam penelitian ini. Populasi yang dipakai ialah perusahaan-perusahaan sektor agrikultur yang tercatat di BEI periode tahun 20142018 menggunakan data laporan keuangan tahunan perusahaan tersebut yang berarti penelitian ini memiliki jenis data sekunder. Tahap analisis data penelitian ini dimulai dengan uji asumsi klasik yang terdiri dari uji normalitas, uji multikolinearitas, uji heteroskedastisitas, dan uji autokorelasi. Setelah memastikan tidak ada penyimpangan model asumsi klasik, tahap analisis data dilanjutkan menuju analisis regresi linear berganda. Tahap analisis data yang terakhir adalah uji hipotesis yang dapat diartikan sebagai jawaban sementara peneliti terhadap rumusan masalah penelitian yang nantinya bentuk rumusan tersebut dinyatakan dalam kalimat pernyataan. Uji hipotesis dalam penelitian ini menggunakan uji statistik F, uji statistik $\mathrm{T}$, dan Koefisien Determinansi $\left(\mathrm{R}^{2}\right)$. Teknik sampling yang diterapkan pada penelitian ini ialah purposive sampling. Dari total 20 perusahaan di sektor agrikultur yang terdaftar selama periode 2014-2018, dilakukan analisis untuk mendapatkan perusahaan yang memenuhi kriteria penelitian ini. Sehingga, didapatkan perusahaan yang berturut-turut listing dan menerbitkan laporan keuangan selama periode 2014-2018 adalah sejumlah 17 perusahaan. 
Lingga Sundagumilar Abqari \& Ulil Hartono. Pengaruh Rasio-rasio Keuangan terhadap Harga Saham Sektor Agrikultur di Bursa Efek Indonesia Periode 2014-2018

\section{HASIL DAN PEMBAHASAN}

\section{Hasil Uji Hipotesis}

Angka koefisiensi sebesar -4.634 $(0<0.05)$ ditunjukkan ketika uji hipotesis dilakukan pada ROE terhadap harga saham. Merujuk pada nilai tersebut, ROE berefek negatif dan signifikan terhadap harga saham sehingga dapat diambil keputusan bahwa $\mathrm{H} 1$ diterima. Uji hipotesis juga dilangsungkan pada EPS terhadap harga saham yang menampakkan hasil angka koefisiensi sebesar $25.635(0<0.05)$. Berlandaskan hasil tersebut, maka EPS berefek positif dan signifikan terhadap harga saham sehingga dapat diputuskan bahwasanya $\mathrm{H} 2$ diterima.

Untuk uji hipotesis pada PER terhadap harga saham dihasilkan angka koefisiensi senilai -2.655 (0.012 $<0.05)$. Maka dapat diputuskan bahwasanya PER memberikan pengaruh negatif dan signifikan apabila dilihat pada nilai tersebut. Artinya, H3 diterima. Sedangkan hasil yang berbeda dimiliki oleh DER ketika dilangsungkan uji hipotesis terhadap harga saham. Nilai $1.774(0.086<0.05)$ adalah hasil yang didapat ketika dilakukan uji tersebut. Oleh sebab itu apabila ditilik pada nilai tersebut, DER tidak mempunyai pengaruh dan signifikansi terhadap harga saham maka dapat diambil keputusan bahwasanya $\mathrm{H} 4$ ditolak.

F hitung yang didapat pada hasil penelitian ini adalah sebesar 217.925 dengan nilai signifikansi 0.000. Sehingga seluruh variabel independen pada penelitian ini yakni ROE, EPS, PER, dan DER secara bersamaan memberikan pengaruh positif terhadap variabel dependen yakni harga saham.

\section{Pengaruh ROE terhadap Harga Saham}

Berdasarkan hasil penelitian, ROE memiliki pengaruh negatif terhadap harga saham. Hal ini didasarkan dari nilai ROE perusahaan sampel yang tidak begitu besar, bahkan beberapa perusahaan banyak yang memiliki nilai ROE negatif yang mengindikasikan bahwa perusahaan-perusahaan tersebut sedang tidak dapat menghasilkan keuntungan dikarenakan periode tersebut memang merupakan periode yang sulit bagi sektor agrikultur. Sehingga, penelitian ini menerima H1 yang artinya perusahaan sektor agrikultur di BEI dengan ROE yang rendah membuat harga sahamnya malah meningkat. Oleh karena itu, para investor dapat menggunakan ROE sebagai acuan dalam pengambilan keputusan investasi. Pengaruh variabel ROE terhadap harga saham bisa dikaitkan dengan signaling theory. Sinyal tersebut berupa sinyal baik maupun sinyal buruk. Sinyal yang baik bisa tercermin pada ROE yang terus menurun sehingga harga saham bisa meningkat, begitu pula sebaliknya, sinyal yang buruk bisa tercermin pada ROE yang terus meningkat sehingga harga saham bisa terus menurun. Hasil penelitian ini mendukung signaling theory, karena rasio ROE yang rendah atau tinggi akan mengirimkan informasi berupa sinyal positif maupun negatif yang dikeluarkan perusahaan, sinyal ini akan memengaruhi pihak eskternal dalam pengambilan keputusan jika ingin berinvestasi pada perusahaan tersebut.

Terdapat data yang mendukung hasil penelitian ini seperti PP London Sumatra Indonesia Tbk pada tahun 2016 mempunyai tingkat rasio ROE sebesar 0.078 dan meningkat menjadi 0.094 pada tahun 2017. Seiring dengan rasio ROE tersebut, PP London Sumatra Indonesia Tbk ternyata mengalami penurunan harga saham dari 1740 pada tahun 2016 menjadi sebesar 1420 pada tahun 2017. Hasil penelitian ini selaras dengan penelitian Hidayat \& Topowijono (2018) yang menunjukkan pengaruh negatif rasio ROE terhadap harga saham yang mengindikasikan bahwa perusahaan sedang tidak menghasilkan keuntungan. Maka, tinggi rendahnya rasio ROE akan memberikan dampak negatif kepada harga saham.

\section{Pengaruh EPS terhadap Harga Saham}

Pengujian hipotesis yang dilakukan pada penelitian ini menunjukkan EPS memberikan positif kepada harga saham, yang artinya H2 diterima. Penelitian ini mendukung penelitian Jiwandono (2014) yang berpendapat apabila rasio EPS semakin tinggi maka akan meningkatkan harga saham, tingginya rasio EPS membuat harga saham turut meningkat. Hal tersebut berarti perusahaan-perusahaan sektor agrikultur yang tercatat di BEI tahun 2014-2018 mempunyai kecukupan laba yang tersedia untuk para pemegang saham. Kondisi demikian diindikasikan dengan perolehan rata-rata rasio EPS perusahaan sektor agrikultur di BEI dalam rentang tahun 2014-2018 adalah sebesar 78.84. Sedangkan, penelitian 
Ramfineli \& Ibrahim (2016) mempunyai hasil yang tidak sama dengan penelitian ini yaitu EPS tidak memberikan pengaruh yang signifikan terhadap harga saham.

Sama halnya dengan ROE, signaling theory dapat digunakan untuk mengetahui hubungan antara EPS terhadap perubahan harga saham, sebab angka EPS yang terkandung pada laporan keuangan perusahaan tersebut dapat memberikan gambaran informasi bagi investor untuk mengetahui prospek earning perusahaan tersebut di waktu mendatang. Semakin tinggi nilai EPS yang terkandung dalam laporan keuangan perusahaan tersebut, maka akan menunjukkan sinyal positif untuk investor. Adapun data yang mendukung hasil penelitian ini seperti pada Astra Agro Lestari Tbk pada tahun 2016 mempunyai tingkat rasio EPS 1042.75 dengan harga saham yang semula 15850 pada tahun 2015 meningkat sebesar 925 menjadi 16775 pada tahun 2016. Begitu pula dengan BISI INTERNATIONAL Tbk di tahun 2014 yang memperoleh rasio EPS sebesar 55.09 dan meningkat menjadi 87.97 di tahun 2015 diiringi dengan peningkatan harga saham sebesar 595 dari 790 di tahun 2014 menjadi 1385 di tahun 2015. Dari data tersebut dapat didapatkan bahwasanya semakin tinggi rasio EPS suatu perusahaan akan meningkatkan harga saham.

\section{Pengaruh PER terhadap Harga Saham}

Penelitian ini menggambarkan adanya hubungan negatif dari PER terhadap harga saham, maka hipotesis ketiga diterima. Hal ini mengindikasikan bahwasanya meningkatnya PER suatu perusahaan sektor agrikultur di BEI periode 2014-2018 dapat menyebabkan menurunya harga saham perusahaan tersebut. Hasil penelitian dari Hidayat dan Topowijono (2018) sejalan dengan penelitian ini yang mendapati hasil PER berpengaruh negatif pada harga saham karena hak tersebut didasarkan dari ratarata perusahaan dari periode penelitian bahwa nilai PER cukup besar bahkan dari tahun ke tahun mengalami peningkatan. Sedangkan pengaruh negatif yang ditemukan dalam penelitian terseut didapat dari beberapa perusahaan yang memiliki nilai PER yang bernilai negatif cukup besar. Sebab itu, perusahaan dengan pertumbuhan dan laba yang baik belum tentu meraih harga saham yang meningkat. Sama seperti EPS dan ROE, signaling theory juga dapat dipakai untuk mengetahui hubungan PER terhadap perubahan harga saham, sebab informasi PER yang terdapat pada laporan keuangan perusahaan tersebut dapat menjadi gambaran informasi bagi investor.

Jaya Agra Wattie Tbk menunjukkan data yang mendukung hasil penelitian ini yaitu pada tahun 2014 didapatkan nilai PER yang sebesar -70.25 meningkat menjadi -2.63 pada tahun 2015. Tapi peningkatan rasio PER tersebut tidak diiringi dengan peningkatan harga saham pula yakni dari harga saham 378 pada tahun 2014 menjadi 220 pada tahun 2015. Terdapat juga PT Sawit Sumbermas Sarana Tbk pada tahun 2017 mendapat nilai PER sebesar 18.15 kemudian meningkat pada tahun 2018 menjadi 24.78 . Ternyata peningkatan nilai PER tersebut malah membuat harga saham semakin turun yakni dengan nilai 1500 pada tahun 2017 menjadi 1250 pada tahun 2018. Sehingga, dari data tersebut didapati bahwasanya semakin kecil nilai dari PER yang dimiliki suatu perusahaan sektor agrikultur di BEI periode 20142018 maka semakin besar harga sahamnya. Begitu pun sebaliknya ketika nilai PER meningkat, maka harga saham perusahaannya akan menurun.

\section{Pengaruh DER terhadap Harga Saham}

Pada hasil penelitian ini terlihat bahwa DER tidak memberikan pengaruh terhadap harga saham, sehingga menolak H4. Kondisi tersebut menunjukkan besar kecilnya rasio DER yang dimiliki perusahaan tidak berpengaruh terhadap tingkat keuntungan yang didapat perusahaan tersebut dengan melihat harga sahamnya. Hal ini disebabkan karena DER adalah perbandingan antara total hutang dengan total modal. Jika manajemen mengambil kebijakan untuk memperbesar hutang berarti manajemen meningkatkan risiko likuiditas yang membuat investor akan merespon kebijakan tersebut sebagai sinyal bahwa di masa depan akan terjadi ketidakmampuan perusahaan untuk membayar kewajiban perusahaan yang tentunya akan berdampak pada penurunan tingkat dividen yang akan diperoleh bagi investor. Akibatnya investor akan melepas saham yang dipunyai dan beralih pada investasi yang lebih menguntungkan dan membuat jumlah saham yang ditawarkan menjadi lebih besar dibanding jumlah saham yang diminta sehingga mengakibatkan harga saham bergerak turun. Penelitian ini sejalan dengan penelitian Daniel (2015) yang juga mempunyai hasil bahwa DER tidak berpengaruh 
terhadap harga saham. Maka penelitian ini tidak mendukung signaling theory karena besar kecilnya DER tidak akan memengaruhi pihak eksternal yang berkepentingan yakni calon investor untuk mengambil keputusan menginvestasikan dananya pada perusahaan tersebut dengan adanya informasi berupa sinyal positif atau negatif yang ditunjukkan oleh naik atau turunnya DER perusahaan.

PT Sawit Sumbermas Sarana Tbk di tahun 2014 mempunyai DER yang tergolong terlampau tinggi yakni 23.49 yang berarti perusahaan tersebut mengambil jumlah utang yang sangat besar atau tingkat kemampuan melunasi kewajibannya sangatlah rendah. Akan tetapi pada tahun 2015 DER perusahaan tersebut jauh menurun menjadi 1.30 saja. Hal itu diiringi dengan peningkatan harga saham mencapai dari 1665 pada tahun 2014 menjadi 1950 pada tahun 2015. Selain itu, Gozco Plantation Tbk pada tahun 2016 meraih rasio DER yang tergolong tinggi sebesar 2.10 namun pada tahun selanjutnya menurun menjadi 1.29. Hal tersebut tidak searah dengan pergerakan harga sahamnya yang menghadapi penurunan dari 75 pada tahun 2016 menjadi 62 pada tahun 2017. Oleh karena itu, atas dasar data yang mendukung tersebut besar kecilnya rasio DER tidak dapat memengaruhi naik turunnya harga saham.

\section{KESIMPULAN}

Beralaskan hasil penelitian maka bisa disimpulkan bahwa, ROE memberikan pengaruh negatif terhadap harga saham. Sehingga, pada penelitian ini menerima $\mathrm{H}_{1}$, yang berarti perusahaan sektor agrikultur di BEI dengan ROE yang rendah membuat harga sahamnya malah meningkat. Pengujian hipotesis yang diujikan penelitian ini menunjukkan hasil EPS memberikan pengaruh positif terhadap harga saham, yang artinya $\mathrm{H}_{2}$ diterima. Penelitian ini menggambarkan adanya hubungan negatif dari PER terhadap harga saham, maka hipotesis ketiga diterima. Hasil penelitian ini menunjukkan bahwa DER tidak berpengaruh terhadap harga saham, sehingga menolak $\mathrm{H}_{4}$. Melalui uji $\mathrm{F}$, dapat dilihat pada penelitian ini bahwa ROE, EPS, PER, dan DER bersamaan memberikan pengaruh terhadap harga saham.

Adapun saran bagi perusahaan adalah supaya lebih memerhatikan factor-faktor yang mampu memberi dampak tehadap harga saham perusahaan serta dalam menghasilkan laba bersih bagi para investor. Saran bagi investor ialah hendaknya menimbang berbagai faktor-faktor yang memberi dampak terhadap harga saham seperti kemampuan perusahaan dalam menghasilkan laba bersih serta persepsi pasar terhadap saham perusahaan tersebut sebelum menginvestasikan dananya pada saham suatu emiten. Kemudian yang bisa disarankan untuk penelitian berikutnya adalah dapat merapatkan periode penelitian dari tahunan menjadi bulanan, mingguan, atau bahkan harian seiring dengan pesatnya perkembangan big data analytics dan memakai variabel-variabel lain yang mampu mempengaruhi harga saham suatu perusahaan atau emiten seperti GPM (Gross Profit Margin), ROI (Return On Investment), ROA (Return On Asset), juga NPM (Net Profit Margin) agar bisa mendapatkan hasil lebih baik dari penelitian ini.

\section{DAFTAR PUSTAKA}

Ananda, A. (2013). Pengaruh Debt to Equity Ratio, Return On Equity, Earning Per Share, dan Price Earning Ratio terhadap Harga Saham (Studi pada Perusahaan Food and Beverages yang Terdaftar di BEI Tahun 2008-2011). Jurnal Administrasi Bisnis S1 Universitas Brawijaya, 4(2), 1-12.

Arifin, N. F., \& Agustami, S. (2016). Pengaruh Likuiditas, Solvabilitas, Profitabilitas, Rasio Pasar, dan Ukuran Perusahaan terhadap Harga Saham (Studi Pada Perusahaan Subsektor Perkebunan yang Terdaftar Di Bursa Efek Indonesia Tahun 2010-2014). Jurnal Riset Akuntansi Dan Keuangan, 4(3), 1189-1210. https://doi.org/10.17509/jrak.v4i3.4673

Artha, D. R., Achsani, N. A., \& Sasongko, H. (2014). Analisis Fundamental, Teknikal dan Makroekonomi Harga Saham Sektor Pertanian. Jurnal Manajemen Dan Kewirausahaan, 16(2), 175-183. https://doi.org/10.9744/jmk.16.2.175

Brigham, E. F., \& Houston, J. F. (2010). Manajemen Keuangan Edisi Kedelapan. In Erlangga Jakarta. https://doi.org/10.1016/0377-841X(78)90069-4 
Daniel. (2015). Pengaruh Faktor Internal terhadap Harga Saham pada Perusahaan LQ 45 yang Terdaftar di Bursa Efek Indonesia. Jurnal EMBA, 3(3), 10-17. https://doi.org/10.1145/3132847.3132886

Hanafi, M. M., \& Halim, A. (2009). Analisis Laporan Keuangan Edisi Keempat. Yogyakarta: UPP STIM YKPN.

Hardjanti, R. (2016). 3 Sektor Komoditas Paling Apes di 2015. Retrieved from okefinance website: https://economy.okezone.com/read/2016/05/12/320/1386584/3-sektor-komoditas-paling-apesdi-2015

Hidayat, D., \& Topowijono. (2018). ( Studi Pada Perusahaan Pertambangan Subsektor Pertambangan Minyak dan Gas Bumi yang terdaftar Dibursa Efek Indonesia Periode 2013-2016 ). Jurnal Administrasi Bisnis, 62(1), 36-44.

Husnan, S., \& Pudjiastuti, E. (2006). Dasar-Dasar Manajemen Keuangan Edisi Kelima. Retrieved from https://scholar.google.com/scholar?cluster=4035149046796202071\&hl=en\&oi=scholarr

Indonesia, B. (2016). Laporan Perekonomian Indonesia Tahun 2015. Retrieved from https://www.bi.go.id/id/publikasi/laporan-tahunan/perekonomian/Pages/LPI_2015.aspx

Inndiarti, D. (2016). Pengaruh Return on Equity (ROE), Price Earning Ratio (PER), dan Debt to Equity Ratio (DER) terhadap Nilai Perusahaan pada Perusahaan Otomotif dan yang Terdaftar di Bursa Efek Indonesia (BEI) Periode 2011-2014 (Polsri Repository). Retrieved from http://eprints.polsri.ac.id/3340/

Investing.com. (2020). IDX Agriculture Index (JKAGRI). Retrieved March 5, 2020, from https://www.investing.com/indices/idx-agriculture

Jiwandono, T. (2014). Analisis Faktor Fundamental terhadap Harga Saham Sektor Perbankan yang Go Public di Indeks Kompas 100. Jurnal Ilmu Manajemen, 2(3), 783-794.

Kamar, K. (2017). Analysis of the Effect of Return on Equity (ROE) and Debt to Equity Ratio (DER) on Stock Price on Cement Industry Listed In Indonesia Stock Exchange (IDX) In the Year of 2011-2015. IOSR Journal of Business and Management, 19(05), 66-76. https://doi.org/10.9790/487x-1905036676

Kasmir. (2012). Analisis Laporan Keuangan. Jakarta: PT. Raja Grafindo Persada.

Kasmir. (2015). Analisis Laporan Keuangan (Satu). Jakarta: PT. Raja Grafindo Persada.

Kodrat, D. S., \& Indonanjaya, K. (2010). Manajemen Investasi : Pendekatan Teknikal dan Fundamental untuk Analisis Saham. Yogyakarta: Graha Ilmu.

Maskun, A. (2012). The Effect of Current Ratio, Return On Equity, Return On Asset, Earning Per Share to the Price of Stock of Go-Public Food and Beverages Company in Indonesian Stock Exchange. International Journal of Academic Research. https://doi.org/10.7813/2075-4124.2012/4-6/b.20

Mehrani, H., \& Syafitri, L. (2013). Pengaruh Return On Investment (ROI), Earning Per Share (EPS), dan Price Earning Ratio (PER) terhadap Harga Saham Pada PT. Indofood Sukses Makmur Tbk. Jurnal Managemen, 02, 9/30. Retrieved from http://eprints.mdp.ac.id/756/1/JURNAL Heny Mehrani.pdf

Munira, M., Merawati, E. E., \& Astuti, S. B. (2018). Pengaruh ROA dan ROE terhadap Harga Saham Perusahaan Kertas di BEI. Jurnal Dinamika Manajemen, 4(3), 191-205. https://doi.org/10.1017/CBO9781107415324.004 
Lingga Sundagumilar Abqari \& Ulil Hartono. Pengaruh Rasio-rasio Keuangan terhadap Harga Saham Sektor Agrikultur di Bursa Efek Indonesia Periode 2014-2018

Ramfineli, R. H., \& Ibrahim, M. (2016). Analisis Kinerja Keuangan dengan Rasio Profitabilitas dan Pengaruhnya terhadap Harga Saham Perusahaan Sektor Industri Dasar dan Kimia Sub Sektro Pulp \& Paper di Bursa Efek Indonesia. Jom FISIP, 3(2), 1-15. Retrieved from https://media.neliti.com/media/publications/116435-ID-analisis-kinerja-keuangan-denganrasio-p.pdf

Saleh, V. A. (2012). Pengaruh Informasi Akuntansi Terhadap Perubahan Harga Saham Perusahaan Petambangan Go Public di Bursa Efek Indonesia. Retrieved from https://docplayer.info/29831128-Pengaruh-informasi-akuntansi-terhadap-perubahan-hargasaham-perusahaan-pertambangan-go-public-di-bursa-efek-indonesia-skripsi.html

Sari, E. I., Safitri, E., \& Ekawati, R. K. (2013). Pengaruh Faktor-Faktor Fundamental terhadap Harga Saham PT Unilever Indonesia Tbk Tahun 2004-2013. Jurnal Ilmiah Ekonomi Bisnis, 19(3), 1-7. Retrieved from http://eprints.mdp.ac.id/750/

Sartono, A. (2008). Manajemen Keuangan Teori dan Aplikasi Edisi Keempat. Yogyakarta: BPPFE.

Setyawan, A. W. P. S. (2012). Pengaruh Komponen Risk Based Bank Rating terhadap Harga Saham Perusahaan Perbankan yang Go Public di Bursa Efek Indonesia (Bei) Tahun 2008-2011 (UNDIPIR). Retrieved from http://eprints.undip.ac.id/35889/1/SKRIPSI_SETYAWAN.pdf

Sewi, P. D. A., \& Suayana, I. G. N. . (2013). Pengaruh EPS, DER, dan PBV terhadap Harga Saham. Akuntansi Universitas Udayana, 1, 215-229.

Sudana, I. M. (2009). Manajemen Keuangan: Teori dan Praktek. Surabaya: Universitas Airlangga.

Tandelilin, E. (2010). Bab 1 Pengertian Investasi. In Portofolio dan Investasi, Teori dan Aplikasi.

Utomo, W. P., \& Hartono, U. (2014). Pengaruh Faktor Fundamental Eksternal dan Internal terhadap Perubahan Harga Saham Perusahaan Sektor Pertambangan. Jurnal Ilmu Manajemen, 2(1), 91103.

Zuliarni, S. (2012). Pengaruh Kinerja Keuangan Terhadap Harga Saham Pada Perusahaan Mining and Mining Service di Bursa Efek Indonesia (BEI). Jurnal Aplikasi Bisnis, 3(1), 36-48. 